\title{
Introduction to the Food Dignity Values Statement
}

\section{FoodDignity}

\author{
Monica Hargraves * \\ Cornell University
}

Submitted June 26, 2018 / Published online July 18, 2018

Citation: Hargraves, M. (2018). Introduction to the Food Dignity Values Statement. Journal of A griculture, F ood

Systems, and Community D evelopment, 8(Suppl. 1), 33-35. https:/ / doi.org/ 10.5304/ jafscd.2018.08A.018

Copyright @ 2018 by the Author. Published by the Lyson Center for Civic Agriculture and Food Systems. Open access under CC BY license.

The Food Dignity Values Statement was drafted at a national project meeting in May 2014, three years into the community-university collaboration that was the Food Dignity action research project. The project brought together academics from four universities and community leaders from five community-based organizations working to strengthen their local food systems. The goal was an action-research collaboration to support and learn from and with these community organizations about how to build equitable, sustainable, and just local food systems: "Food dignity as a premise and Food Dignity as a research project are both steeped in recognizing that community people hold the knowledge and ability to ask the right questions

* Monica Hargraves, Associate Director for Evaluation Partnerships, Cornell Office for Research on Evaluation, Cornell University; 35 Thornwood D rive, Suite 200, Room 150-C; Ithaca NY 14850 USA; mjh51@ cornell.edu

\section{Author Disclosure}

Hargraves serves on the board of directors and consults for Action Resources International, the sponsoring organization for Feeding Laramie Valley, one of the community organizations partnering in the Food Dignity project. and find the right answers to their own needs" (Porter, Herrera, Marshall, \& Woodsum, 2014, p. 124).

An ethical sensibility was part of the project from the beginning. The grant proposal narrative itself had declared that "O ur project title, 'Food Dignity,' signals both our ethical stance that human and community agency in food systems is an end in itself and our scientific hypothesis that building civic and institutional capacity to engage in [sustainable community food systems] for [food security] action will improve the sustainability and equity of our local food systems and economies" (Food Dignity, 2010). But as we learned in the

\section{Funding Disclosure}

Food Dignity (http:/ / www.fooddignity.org) was funded by USD A National Institute of Food and Agriculture's Agriculture and Food Research Initiative Competitive G rant no. 2011-68004-30074.

\section{Contributors and Supporting Agencies}

Blue Mountain Associates; Feeding Laramie Valley; Whole Community Project; East New York Farms!; Dig D eep Farms; University of Wyoming; and the U.S. D epartment of Agriculture National Institute of Food and Agriculture. 
course of the project's internal struggles over voice, research design, ways of working, and knowledge hierarchies, it is a long journey from ethical goals to operationalized, lived, and shared values (for example, in this issue see Hargraves, Porter, \& Woodsum, 2018; Porter, 2018; Porter \& Wechsler, 2018; Woodsum, 2018).

The declared commitment in the Food Dignity project to seeking, welcoming, respecting, and making place for diverse ways of knowing and sharing information was both personally and professionally challenging for many in the project. Tense national project meetings and side conversations in which the gulf between academic and community experiences and approaches played out led us to incorporate workshops on structural racism and systemic oppression, and to hire a facilitator to assist us during our national project meeting in Detroit in 2012. Those efforts- as well as growing mutual understanding from site visits to all the partnering community organizations, informal interactions, and growing relationships across all the divides- made the work intense, but slowly strengthened our ability to collaborate.

Progress remained uneven, however. As our May 2014 national meeting approached, several people in the project (myself among them) felt a need for an articulated set of values that could be used to improve clarity, shared commitment, and accountability. A "Food Dignity Values" option was added to the concurrent discussion sessions at that national meeting. A small group of participants developed a draft statement during that session. The full group at the meeting reviewed, amended, and later approved the statement of values below.

The statement is not a description of what we succeeded in doing in the Food Dignity project. True collaboration across divides of power, culture, and purpose is difficult-perhaps impossible if the structures that sustain and perpetuate those divides

\section{Food Dignity Values Statement \\ Adopted May 2014}

We value the fundamental dignity, worth, sovereignty, self-determination and the inherent power of all people. As members of the Food Dignity project, we are committed to principles and ways of working within our own work and in the changes we wish to inform and inspire in the world, by:

- combating all forms of racism, oppression and implicit bias;

- respecting and valuing the individual and shared journeys of the people, the project and the histories of our communities, including historical trauma;

- valuing authentic first-person voice and first-person knowledge;

- valuing the different ways that people live, work and relate to each other;

- valuing the act of listening and specifically listening long enough to achieve shared meaning;

- valuing seeing and being seen, listening and being heard, becoming real to each other, recognizing that an important kind of knowing is experiential and lived;

- valuing accountability to one another and to the work for both the intention and impact of our words and actions;

- and persevering through the challenges that come with our inclusion and engagement of differences

as we strive to achieve equity for every human being and personal, institutional, structural and systemic transformations. 
are not dismantled. We learned a great deal, but we fell short in many ways. Nevertheless, the guidance in the values statement reflected hard-won insights and captured our aspirations for how collaborations ought to work.

\section{References}

Food Dignity. (2010). Project Narrative. Part of a grant proposal for "Food Dignity: Action research on engaging food insecure communities and universities in building sustainable community food systems." Submitted to the FY 2010 Global Food Security Request for Applications from the USD A National Institute of Food and Agriculture's Agriculture and Food Research Initiative Competitive Grants Program.

Hargraves, M., Porter, C. M., \& Woodsum, G . M. (2018). Leading Food Dignity: Why us?. Journal of A griculture, F ood Systems, and Community D evelopment, 8(Suppl. 1), 27-31. https:/ / doi.org/ 10.5304/ jafscd.2018.08A.026

Porter, C. M. (2018). Triple-rigorous storytelling: A PI's reflections on devising case study methods with five community-based food justice organizations. Journal of A griculture, F ood Systems, and C ommunity D evelopment, 8(Suppl. 1), 37-61. https:/ / doi.org/ 10.5304/ jafscd.2018.08A.008

Porter, C. M., Herrera, H., Marshall, D ., \& Woodsum, G. M. (2014). Shared voices, different worlds: Process and product in the Food Dignity action research project. $\mathrm{G}$ ateways: International Journal of $\mathrm{C}$ ommunity Research and E ngagement, 7(1), 116-128. https:/ / doi.org/ 10.5130/ ijcre.v7i1.3399

Porter, C. M., \& Wechsler, A. (2018). Follow the money: Resource allocation and academic supremacy among community and university partners in Food Dignity. Journal of A griculture, F ood Systems, and Community D evelopment, 8(Suppl. 1), 63-82. https:/ / doi.org/ 10.5304/ jafscd.2018.08A.006

Woodsum, G. M. (2018). The costs of community-based action research: Examining research access and implementation through the Food D ignity project community support package. Journal of A grialture, F ood Systems, and C ommunity D evelopment, 8(Suppl. 1), 83-99. https:/ / doi.org/ 10.5304/ jafscd.2018.08A.021 